\title{
Selected methods of rehabilitation in systemic sclerosis
}

\author{
Wybrane metody rehabilitacji w twardzinie układowej
}

\author{
Agnieszka Gerkowicz', Angelika Bielecka², Justyna Buś², Beata Polkowska-Pruszyńska², Dorota Krasowska' \\ 'Chair and Department of Dermatology, Venerology and Paediatric Dermatology, Medical University of Lublin, Poland \\ ${ }^{2}$ Student's Scientific Association at the Chair and Department of Dermatology, Venerology and Paediatric Dermatology, Medical \\ University of Lublin, Poland \\ 'Katedra i Klinika Dermatologii, Wenerologii i Dermatologii Dziecięcej Uniwersytetu Medycznego w Lublinie, Polska \\ ${ }^{2}$ Studenckie Koło Naukowe przy Katedrze i Klinice Dermatologii, Wenerologii i Dermatologii Dziecięcej Uniwersytetu Medycznego \\ w Lublinie, Polska
}

\author{
CORRESPONDING AUTHOR/ \\ ADRES DO KORESPONDENCJI: \\ dr n. med. Agnieszka Gerkowicz \\ Katedra i Klinika Dermatologii, \\ Wenerologii i Dermatologii \\ Dziecięcej \\ Uniwersytet Medyczny w Lublinie \\ ul. Radziwiłłowska 13 \\ 20-080 Lublin, Polska \\ tel.: +48 815323647 \\ e-mail: agerkowicz@wp.pl
}

\begin{abstract}
Systemic sclerosis is a chronic connective tissue disease characterized by microvascular abnormalities, immune disturbances and progressive fibrosis of the skin and internal organs. Skin involvement may result in contractures, leading to marked loss of hand mobility, adversely affecting the performance of daily activities and decreasing the quality of life. Face involvement not only causes functional loss, but also lowers the self-esteem of patients. Increasing attention has recently been focused on the need to rehabilitate patients with systemic sclerosis in order to prevent the development of joint contractures and loss of mobility. The study presents a review of the current literature on rehabilitation possibilities in patients with systemic sclerosis, with a special focus on physiotherapy methods.
\end{abstract}

\section{STRESZCZENIE}

Twardzina układowa jest przewlekłą chorobą tkanki łącznej charakteryzującą się występowaniem zmian w mikrokrążeniu, obecnością zaburzeń immunologicznych oraz postępującym włóknieniem skóry i narządów wewnętrznych. Objęcie procesem chorobowym skóry może prowadzić do tworzenia się przykurczów, co w znacznym stopniu ogranicza sprawność rąk, utrudnia wykonywanie czynności dnia codziennego, jak również wpływa na jakość życia chorych. Zmiany w obrębie twarzy także ograniczają sprawność oraz obniżają samoocenę pacjentów. Ostatnio coraz częściej zwraca się uwagę na potrzebę prowadzenia $\mathrm{u}$ chorych $\mathrm{z}$ twardziną układową rehabilitacji mającej na celu zapobieganie powstawaniu przykurczów i ograniczeniu sprawności. W pracy przedstawiono przegląd piśmiennictwa dotyczącego możliwości zastosowania rehabilitacji u pacjentów z twardziną układową, ze szczególnym uwzględnieniem metod fizjoterapii.

Key words: physiotherapy, systemic sclerosis, rehabilitation.

Słowa kluczowe: fizjoterapia, twardzina układowa, rehabilitacja. 


\section{INTRODUCTION}

Systemic sclerosis (SSc) is a chronic connective tissue disease characterized by progressive fibrosis of the skin and internal organs, microvascular abnormalities and the presence of autoantibodies [1-3]. An analysis of data collected by the National Institute of Public Health for the period 2008-2012 shows that the prevalence of systemic sclerosis in Poland at the end of 2012 was 9.4 cases per 100,000 population, and its incidence was estimated at 1.9 cases per 100,000 population a year [4]. SSc affects women more frequently than men, and its characteristic manifestations usually begin between 30 and 50 years of age. The disease is rarely seen in children and the elderly $[4,5]$.

The disease process in systemic sclerosis involves not only the skin but also internal organs including the lungs, cardiovascular system, digestive tract or kidneys. Consequently, the clinical course of the disease varies significantly, depending on factors including the development of organ complications [6].

The two most common clinical forms of the disorder include limited systemic sclerosis (ISSc) and diffuse systemic sclerosis (dSSc). These forms differ with respect to the area of the affected skin, clinical course and prognosis. Limited systemic sclerosis has a chronic course, and usually involves the face and distal extremities, with internal organ complications arising typically at a later stage. Unlike ISSc, dSSc is characterized by a rapid progression and uncertain prognosis. Skin thickenimg and tightening is confined to the trunk, proximal extremities and face, while internal organ abnormalities, as a rule, develop relatively early [6].

Regardless of the development of internal organ abnormalities, the loss of skin elasticity, and thickening and tightening of the skin are the key clinical features of the disease. The initial stage of the disease is marked by the development of oedema localized mainly within the fingers. Then the skin becomes thickened and hardened, which reduces hand mobility [7]. Some patients may develop painful ulcerations on the fingertips. The advanced stage of the disease involves flexion contractures in the joints of the fingers, giving them a claw-like appearance [8]. All the changes described above cause varying degrees of difficulty in performing daily activities [9]. Approximately $90 \%$ of patients with systemic sclerosis report the loss of hand mobility [10]. An assessment of hand function can be performed with the HAMIS test (Hand Mobility in Scleroderma Test). HAMIS evaluates a number of parameters including finger flexion, extension and abduction, abduction of the thumb, thumb pincer grip, dorsal extension and volar flexion of the wrist, and forearm pronation and supi-
WSTĘP

Twardzina układowa (systemic sclerosis - SSc) jest przewlekłą chorobą tkanki łącznej charakteryzującą się postępującym włóknieniem skóry i narządów wewnętrznych, występowaniem zaburzeń w mikrokrążeniu oraz obecnością autoprzeciwciał [1-3]. Na podstawie analizy danych zgromadzonych $\mathrm{w} \mathrm{Na}-$ rodowym Instytucie Zdrowia Publicznego w latach 2008-2012 chorobowość SSc w Polsce na koniec 2012 r. wynosiła 9,4/100 000 osób, natomiast zachorowalność 1,9/100 000 osób rocznie [4]. Twardzina układowa częściej występuje u kobiet niż u mężczyzn, a jej charakterystyczne objawy pojawiają się zwykle między 30. a 50. rokiem życia. Choroba rzadko spotykana jest u dzieci i osób starszych [4,5].

W przebiegu SSc procesem chorobowym objęta jest nie tylko skóra, lecz także narządy wewnętrzne, takie jak płuca, układ sercowo-naczyniowy, przewód pokarmowy czy nerki. $Z$ tego powodu choroba ta charakteryzuje się bardzo zróżnicowanym przebiegiem klinicznym, który zależy między innymi od występowania powikłań narządowych [6].

Najczęściej występują dwie postacie kliniczne: twardzina układowa z ograniczonymi stwardnieniami (limited systemic sclerosis - 1SSc) i twardzina układowa $\mathrm{z}$ uogólnionymi stwardnieniami (diffuse systemic sclerosis - dSSc). Postacie te różnią się lokalizacją zajętej skóry oraz przebiegiem klinicznym i rokowaniem. Twardzina układowa z ograniczonymi stwardnieniami przebiega przewlekle, zwykle zajmuje twarz i dystalne części konczyn, a powikłania narządowe pojawiają się przeważnie w późniejszym okresie. Twardzinę układową z uogólnionymi stwardnieniami charakteryzuje gwałtowny przebieg i niepewne rokowanie. Stwardnienia skóry obejmują tułów, bliższe części kończyn oraz twarz, natomiast zmiany narządowe pojawiają się najczęściej stosunkowo wcześnie [6].

Niezależnie od występowania zmian narządowych utrata elastyczności skóry, jej pogrubienie i twardnienie stanowi jedną z najważniejszych cech klinicznych. W początkowym okresie choroby obserwuje się występowanie obrzęku, głównie w obrębie palców, następnie skóra ulega pogrubieniu i stwardnieniu, co ogranicza ruchomość ręki [7]. U części chorych na opuszkach palców mogą się pojawić bolesne owrzodzenia. W fazie zaawansowanej często stwierdza się przykurcze zgięciowe w stawach palców rąk, co nadaje im wygląd przypominający szpony [8]. Wszystkie opisane powyżej zmiany w różnym stopniu ograniczają wykonywanie czynności dnia codziennego [9]. Wykazano, że ok. 90\% pacjentów z SSc zgłasza utratę sprawności ręki [10]. W celu oceny jej funkcji zaleca się przeprowadzenie testu HAMIS (Hand Mobility in Scleroderma Test). W trakcie badania ocenia się m.in. zginanie, prostowanie i odwodzenie palców, odwodzenie kciuka, 
nation. Each parameter is graded on a 0-3 scale, with 0 representing normal function and 3 - total inability to perform a movement. The maximum possible score of 27 means a complete loss of hand mobility [9].

Cutaneous lesions are often localized on the face which, acquires a mask-like appearance due to thickening of the skin and mucous membranes as well as mandibular resorption. Characteristic manifestations of the disease include reduced mouth aperture (microstomy) and narrowing of the mouth width. All theseabnormalities trigger problems not only with wide opening of the mouth but also sticking out the tongue, which has a considerably adverse effect on the ability to consume foods and maintain proper oral hygiene. In addition, they have a negative impact on dental treatment [11].

On account of internal organ complications and involvement of the musculoskeletal system and the skin, advanced-stage SSc may lead to severe disability [8]. Increasingly, attention has been drawn to the problem of work incapacity in patients with SSc. Sharif et al. have demonstrated incapacity for work in $43.7 \%$ of patients already at an early stage of systemic sclerosis [12]. Consequently, it is essential to provide patients with comprehensive and individually adjusted therapy. The most common treatment is the so-called organ-specific therapy, which differs depending on the clinical form of systemic sclerosis. The introduction of therapy should not be delayed, since the disease has a progressive course and the main goal of treatment is to slow down the advancement of organ complication [6].

Despite the availability of multiple drugs, the problem of progressive impairment of physical function in patients with SSc still persists, and cannot be resolved solely with pharmacological therapy. Consequently, a growing focus is being put on rehabilitative treatment which, it is claimed, should be introduced in the form of rehabilitation programmes adjusted to the activity of the disease [6].

The study presents a review of the current literature on rehabilitation possibilities in patients with systemic sclerosis, with a special focus on physiotherapy methods.

\section{HAND REHABILITATION}

Depending on the stage of the disease, the severity of hand abnormalities may vary. The early stage is often marked by digital oedema. Furthermore, such lesions may be one of the first signs of the disease onset. In addition to the hands, oedema may also involve the face and gradually spread to the extremities or the trunk [13]. It is important to note that the development of digital oedema may limit not only the mobility but also the function of the hand chwyt szczypcowy, zginanie grzbietowe i dłoniowe nadgarstka oraz nawracanie i odwracanie przedramion. Za każdy oceniany parametr pacjent może otrzymać 0-3 pkt, przy czym 0 oznacza prawidłową funkcję, a 3 pkt przyznaje się w przypadku całkowitej niemożności wykonania danego ruchu. Maksymalna liczba punktów wynosi 27 i oznacza całkowity brak sprawności ręki [9].

Częstą lokalizacją zmian skórnych jest twarz, która ze względu na włóknienie skóry, błony śluzowej, a także resorpcję kości żuchwy ma wygląd maskowaty. Charakterystycznym objawem są zwężenie szpary ustnej, tzw. mikrostomia, oraz zwężenie czerwieni wargowej. Wszystkie te zmiany powodują problemy nie tylko z szerokim otwieraniem ust, lecz także z wysuwaniem języka, co znacząco wpływa na możliwość przyjmowania pokarmów, utrzymania prawidłowej higieny jamy ustnej, a także utrudnia prowadzenie leczenia stomatologicznego [11].

Ze względu na powikłania narządowe, zajęcie procesem chorobowym układu mięśniowo-stawowego i skóry SSc w fazie zaawansowanej może prowadzić do ciężkiego inwalidztwa [8]. Coraz częściej zwraca się uwagę na występującą u chorych niezdolność do pracy. Sharif i wsp. wykazali niezdolność do pracy u 43,7\% pacjentów już we wczesnym okresie SSc [12]. Dlatego konieczne jest prowadzenie kompleksowej i indywidualnie dobranej terapii. Najczęściej stosuje się tzw. terapię narządowo swoistą, która różni się w zależności od postaci twardziny. Nie należy zwlekać z jej rozpoczęciem, ponieważ choroba ma przebieg postępujący, a głównym celem leczenia jest spowolnienie progresji zmian narządowych [6].

Pomimo wielu dostępnych leków nadal istnieje problem postępującego upośledzenia sprawności pacjentów z SSc, który nie może być rozwiązany wyłącznie terapią farmakologiczną. Dlatego coraz częściej zwraca się uwagę na potrzebę wprowadzenia leczenia rehabilitacyjnego w postaci programów dostosowanych do aktywności choroby [6].

W pracy przedstawiono przegląd piśmiennictwa dotyczącego możliwości zastosowania rehabilitacji w SSc ze szczególnym uwzględnieniem różnych metod fizjoterapii.

\section{REHABILITACJA RĘKI}

W zależności od fazy choroby zmiany w obrębie ręki mogą być różnie nasilone. We wczesnym okresie często stwierdza się obrzęk palców. Ponadto zmiany te mogą być jednym z pierwszych objawów rozpoczynającej się choroby. Oprócz rąk, obrzęk może się pojawić również w obrębie twarzy, a następnie szerzyć się na kończyny czy tułów [13]. Warto podkreślić, że pojawienie się obrzęku palców może ograniczyć nie tylko ruchomość, lecz także spraw- 
[13]. At an early stage of the disease, particularly when oedema is present, the recommended method is manual lymphatic drainage [13]. At later stages, marked by thickening and tightening of the skin, the purpose of treatment is to prevent joint contractures and improve hand function. Therefore, the recommended strategy in more advanced disease stages is the combination of various methods of physiotherapy complemented by exercise programmes that can be completed by patients at home [14, 15].

\section{MANUAL LYMPHATIC DRAINAGE}

In addition to microvascular disorders, patients with SSc may also be affected by lymphatic system abnormalities, particularly in the upper extremities [13]. Such patients may benefit from manual lymphatic drainage (MLD) especially at an early disease stage when oedema develops. Manual lymphatic drainage stimulates the lymphatic system, increasing the suction forces in lymphatic vessels, which improves the removal of excess fluid accumulated in the interstitial tissue. In addition, MLD activates the parasympathetic nervous system, resulting in vasodilation $[16,17]$.

Manual lymphatic drainage is performed using basic Vodder strokes. The average tissue compression should be ca. $30 \mathrm{~mm} \mathrm{Hg}$, followed by a relaxation phase. In accordance with the Vodder technique, the massage should begin in the triangular area at the base of the neck above the clavicles, called the "terminus". Next, the lymphatic vessels and lymph nodes of the head and neck are massaged. The subsequent stage involves massaging the upper extremity starting with the most proximal part and moving down from the arm to the wrist and then the dorsal and palmar surfaces of the hand in order to open lymphatic vessels. As the final element, the upper extremity is massaged in the centripetal direction in order to evacuate the lymph [13]. The massage should be performed in both upper extremities beginning with the one with less oedema. The mean duration of the procedure is approximately $1 \mathrm{~h}$ [13].

To date, there have been a few studies addressing the possibilities for using MLD in patients with SSc $[13,18]$. A particularly interesting study evaluated the efficacy of MLD in 35 patients with systemic sclerosis. Manual lymphatic drainage was performed once a week for a total of 5 weeks in the study group ( $n$ $=20)$. Subjects in the control group $(n=15)$ did not undergo any rehabilitation. After the completion of the treatments, the hand volume, HAMIS score and VAS (Visual Analogue Scale) parameters used for the evaluation of symptoms reported by the subjects, including hand oedema, pain, and their effect on the performance of daily activities were shown to have ność ręki [13]. Metodą rekomendowaną we wczesnej fazie choroby, zwłaszcza w przypadku obecności obrzęków, jest manualny drenaż limfatyczny [13]. W późniejszym okresie, kiedy dochodzi do włóknienia, leczenie ma na celu zapobieganie przykurczom w stawach i zwiększenie sprawności ręki. Dlatego w późniejszym okresie choroby zaleca się połączenie różnych metod fizjoterapii uzupełnianych o programy domowych ćwiczeń wykonywanych samodzielnie przez pacjentów $[14,15]$.

\section{MANUALNY DRENAŻ LIMFATYCZNY}

U pacjentów z SSc, obok zaburzeń w mikrokrążeniu, mogą być obecne zaburzenia w krążeniu limfatycznym, zwłaszcza w obrębie kończyn górnych [13]. Z tego powodu można stosować manualny drenaż limfatyczny (MDL), szczególnie we wczesnej fazie choroby, kiedy pojawiają się obrzęki. Metoda ta stymuluje układ limfatyczny, powodując wzrost sił ssących w naczyniach limfatycznych, co usprawnia usuwanie nadmiaru płynu zgromadzonego w tkance śródmiąższowej. Dodatkowo MDL pobudza układ przywspółczulny, co prowadzi do rozszerzenia naczyń $[16,17]$.

W MDL wykorzystuje się podstawowe chwyty Voddera. Średni nacisk tkanek powinien wynosić ok. $30 \mathrm{~mm} \mathrm{Hg}$, po czym następuje faza odprężenia. Zgodnie z techniką Voddera masaż rozpoczyna się od trójkątnego obszaru zwanego terminus u podstawy szyi ponad obojczykami. Następnie przeprowadza się masaż w obrębie naczyń i węzłów chłonnych głowy i szyi. Kolejnym etapem jest masaż kończyny górnej, który zaczyna się od najbardziej proksymalnej części, przechodząc kolejno od ramienia do nadgarst$\mathrm{ka}$, a następnie powierzchni grzbietowej i dłoniowej ręki, co ma na celu opróżnienie naczyń limfatycznych. Na zakończenie wykonuje się masaż w obrębie kończyny górnej w kierunku dośrodkowym w celu odprowadzenia chłonki [13]. Rekomendowane jest przeprowadzenie masażu w obrębie obu kończyn górnych, zaczynając od mniej obrzękniętej. Średni czas trwania to ok. 1 godziny [13].

Dotychczas w pojedynczych badaniach przedstawiono możliwość zastosowania MDL u chorych z SSc $[13,18]$. Szczególnie ciekawe wydaje się badanie, w którym oceniono skuteczność MDL u 35 chorych z SSc. W grupie badanej $(n=20)$ MDL wykonywano 1 raz $\mathrm{w}$ tygodniu przez 5 tygodni, natomiast grupa kontrolna $(n=15)$ nie była poddana żadnej rehabilitacji. Po zakończeniu zabiegów w badanej grupie objętość ręki, test HAMIS, parametry skali wizualno-analogowej VAS (Visual Analogue Scale) stosowanej do oceny zgłaszanych przez chorych objawów, takich jak obrzęk rąk, ból, oraz ich wpływ na wykonywanie codziennych czynności poprawiły się znacząco 
improved significantly $(p<0.0001)$ in the study group compared to the baseline. What is more, the effect persisted for 9 weeks after the completion of therapy. No changes were observed in the control group, where the subjects did not undergo MLD. Manual lymphatic drainage was found to have a beneficial effect on improving the quality of life of patients and their overall functioning evaluated with several questionnaires including: HAQ (Health Assessment Questionnaire), PSI (Physical Synthetic Index), SF-36 (Short Form 36) and MSI (Mental Synthetic Index). The authors suggest that the continuation of therapy at home may lead to a steady decrease in oedema and improvement in hand function, and prolong the beneficial effect of therapy [13].

\section{TECHNIQUES IMPROVING HAND FUNCTION}

\section{Connective tissue massage}

Connective tissue massage (CTM) is a manual technique which improves blood circulation and helps to release tension in pathologically altered tissues through their stretching. Connective tissue massage should be performed on the hand and forearm, and the procedure should take approximately $10 \mathrm{~min}$ for each extremity $[13,15]$. It is believed that CTM may induce a temporary improvement, however it does not result in permanent elimination of symptoms [19]. Consequently, the technique should preferably be combined with other physiotherapy procedures.

\section{Mc Mennell joint manipulation}

Mc Mennell joint manipulation is a technique aiming to recover the "joint play", i.e. involuntary range of motion on multiple planes. In addition to improving the mobility of hand joints, it reduces pain and contributes to the stretching of periarticular structures. The procedure begins with the manipulation of the wrist and then continues distally towards the metacarpophalangeal and interphalangeal joints. The recommended duration of the procedure is about $15 \mathrm{~min}$ per each hand. In some patients Mc Mennell joint manipulation may be followed by an additional 5-minute session of connective tissue massage $[13,15]$.

So far, the possibilities for using combined physiotherapy methods (connective tissue massage and Mc Mennell joint manipulation) have been assessed in a few studies. Maddali Bongi et al. have demonstrated a beneficial effect of twice weekly hour-long treatments on hand function and on the quality of life in 10 patients with SSc. A statistically significant improvement was noted after 9 weeks in the study group with respect to all parameters measured with questionnaires including MSI, PSI, SF-36, HAQ, $(p<0,0001)$ w porównaniu z wartościami wyjściowymi. Co więcej, efekt ten utrzymywał się jeszcze 9 tygodni po zakończeniu terapii. W grupie kontrolnej, w której nie wykonywano MDL, nie obserwowano zmian. Zastosowanie MDL wpłynęło na poprawę jakości życia chorych oraz poprawę ogólnego funkcjonowania ocenianą za pomocą kwestionariuszy: HAQ (Health Assessment Questionnaire), PSI (Physical Synthetic Index), SF-36 (Short Form 36) i MSI (Mental Synthetic Index). Autorzy sugerują, że kontynuowanie terapii w domu może prowadzić do dalszego zmniejszenia obrzęku oraz zwiększenia sprawności ręki i daje szansę na wydłużenie korzystnego efektu terapii [13].

\section{TECHNIKI POPRAWIAJACE SPRAWNOŚĆ RELKI}

\section{Masaż tkanki łącznej}

Masaż tkanki łącznej jest techniką manualną, która poprawia przepływ krwi oraz pozwala rozluźnić objęte procesem chorobowym tkanki poprzez ich rozciąganie. Rekomenduje się przeprowadzenie masażu tkanki łącznej w obrębie przedramienia i ręki, przy czym średni czas powinien wynosić ok. 10 minut na każdą kończynę [13, 15]. Uważa się, że masaż tkanki łącznej może spowodować czasową poprawę, jednak nie prowadzi do długotrwałego ustąpienia objawów [19]. Dlatego zaleca się łączenie go z innymi zabiegami fizjoterapeutycznymi.

\section{Manipulacje stawowe techniką Mc Mennella}

Manipulacje stawowe techniką Mc Mennella to metoda, która umożliwia odzyskanie tzw. joint play, to znaczy swobodnego, czynnego zakresu ruchu w wielu płaszczyznach. Oprócz poprawy ruchomości stawów ręki, powoduje zmniejszenie bólu i przyczynia się do rozciągania struktur okołostawowych. Zabieg rozpoczyna się w obrębie nadgarstka, następnie kontynuowany jest $\mathrm{w}$ kierunku dystalnym, obejmując kolejno stawy śródręczno-paliczkowe i międzypaliczkowe. Zalecany czas trwania to ok. 15 min na każdą kończynę. W niektórych przypadkach po zakończeniu można jeszcze przeprowadzić dodatkową 5-minutową sesję masażu tkanki łącznej $[13,15]$.

Możliwość zastosowania skojarzonych metod fizjoterapii, takich jak masaż tkanki łącznej oraz manipulacje w stawach techniką Mc Mennella, oceniano dotychczas w pojedynczych badaniach. Maddali Bongi i wsp. stwierdzili korzystny wpływ godzinnych zabiegów prowadzonych 2 razy w tygodniu nie tylko na sprawność ręki, lecz także na poprawę jakości życia u 10 pacjentów z SSc. W grupie badanej po 9 tygodniach wykazano istotną statystycznie poprawę we wszystkich parametrach mierzonych kwestionariuszami: MSI, PSI, SF-36, HAQ, testem HAMISA, skalą Duruöz oraz 
HAMIS test, Duruöz Hand Index and fist closure test, as compared to baseline values. There were no changes in the control group $(n=10)$, where no physiotherapy was used. During 9 weeks after the end of the study the improvement in hand function was maintained only in terms of the HAMIS score [18]. In another study, the authors compared the efficacy of connective tissue massage and Mc Mennell joint manipulation performed for an hour twice a week in combination with a home exercise programme (20 min a day) in 20 patients with SSc. Patients from the control group $(n=20)$ performed only home exercises. After 9 weeks, a statistically significant improvement in parameters assessing hand function and mobility was found in the study group. What is more, the effect persisted 9 weeks after the end of the therapy. Similarly to the previous study, a positive effect on the patients' quality of life was observed mainly during the rehabilitation. In the control group, self-administered exercises improved only the degree of fist closure, however the effect was not sustained 9 weeks after the discontinuation of the exercise regime [15].

\section{Home exercises}

In addition to treatments administered by a qualified physiotherapist, it is also stressed that patients with systemic sclerosis should perform simple exercises by themselves. According to a protocol developed by a group of Italian researchers, patients were advised to exercise for 20 about min daily, with exercises comprising finger flexion and extension, abduction and adduction, touching the thumb with fingers 2 to 4 , wrist flexion and extension, and forearm supination and pronation [15] (Fig. 1). During a year-long study, Mugii et al. demonstrated a beneficial impact of finger stretching exercises self-administered by patients. The researchers found a significant improvement in the range of passive movement in all fingers after just a month of the therapy. The effect was either sustained or improved towards the end of the study period. Moreover, the range of passive motion in the finger joints was found to have increased significantly regardless of the duration and severity of skin lesions caused by systemic sclerosis [20].

\section{Combined techniques - paraffin baths and exercise}

Paraffin baths enable the transfer of heat through the skin surface into deeper tissues, which blocks the inflammatory process, relieves pain, increases blood flow and may contribute to improving tissue elasticity. The heating of body tissues to $40-45^{\circ} \mathrm{C}$ has been shown to reduce stiffness in the metacarpophalangeal joints by testem zaciskania pięści w porównaniu z wartościami wyjściowymi. W grupie kontrolnej $(n=10)$, w której nie prowadzono żadnej fizjoterapii, nie obserwowano zmian. W trakcie kolejnych 9 tygodni po zakończeniu badania poprawa sprawności ręki utrzymała się jedynie w teście HAMISA [18]. W innym badaniu autorzy porównali skuteczność masażu tkanki łącznej i manipulacji w stawach metodą Mc Mennella prowadzonego 2 razy w tygodniu przez godzinę w połączeniu z programem ćwiczeń domowych (20 min dziennie) u 20 pacjentów z SSc. Pacjenci z grupy kontrolnej $(n=20)$ wykonywali jedynie ćwiczenia domowe. Po 9 tygodniach istotną statystycznie poprawę parametrów oceniających funkcje i sprawność ręki stwierdzono w grupie badanej. Efekt ten utrzymał się również 9 tygodni po zakończeniu terapii. Podobnie jak w poprzednim badaniu pozytywny wpływ na jakość życia pacjentów obserwowano głównie w czasie prowadzenia rehabilitacji. W grupie kontrolnej samodzielne wykonywanie ćwiczeń korzystnie wpłynęło jedynie na zwiększenie stopnia zaciśnięcia ręki w pięść, ale efekt ten nie utrzymał się po 9 tygodniach od zaprzestania wykonywania ćwiczeń [15].

\section{Ćwiczenia domowe}

Oprócz zabiegów prowadzonych przez wykwalifikowanego fizjoterapeutę u pacjentów z SSc konieczne jest wykonywanie samodzielnie prostych ćwiczeń. W schemacie ćwiczeń domowych opracowanych przez grupę włoskich badaczy zaleca się, aby pacjent codziennie przez ok. 20 min zginał, prostował, odwodził i przywodził palce, starał się palcami od 2. do 4 . dotknąć kciuka, wykonał zgięcie i prostowanie w obrębie nadgarstka, jak również odwracanie i nawracanie przedramion [15] (ryc. 1). Mugii i wsp. w czasie trwającego rok badania wykazali korzystny wpływ samodzielnie wykonywanych przez pacjentów ćwiczeń rozciągających palce ręki. Badacze stwierdzili istotną statystycznie poprawę w zakresie ruchów biernych wszystkich palców już po miesiącu. Efekt ten utrzymał się lub uległ poprawie pod koniec badania. Ponadto zakres ruchów biernych w stawach palców zwiększył się istotnie, niezależnie od czasu trwania i nasilenia zmian skórnych w przebiegu SSc [20].

\section{Techniki łączone - kąpiele parafinowe oraz ćwiczenia}

Zastosowanie kąpieli parafinowych pozwala na przekazanie ciepła przez powierzchnię skóry do głębiej leżących tkanek, co hamuje proces zapalny, uśmierza ból, zwiększa przepływ krwi i może się przyczynić do wzrostu elastyczności tkanek. Wykazano, że ogrzanie tkanek do temperatury $40-45^{\circ} \mathrm{C}$ zmniejsza sztywność w stawach śródręczno-paliczkowych o ok. 20\% [8, 


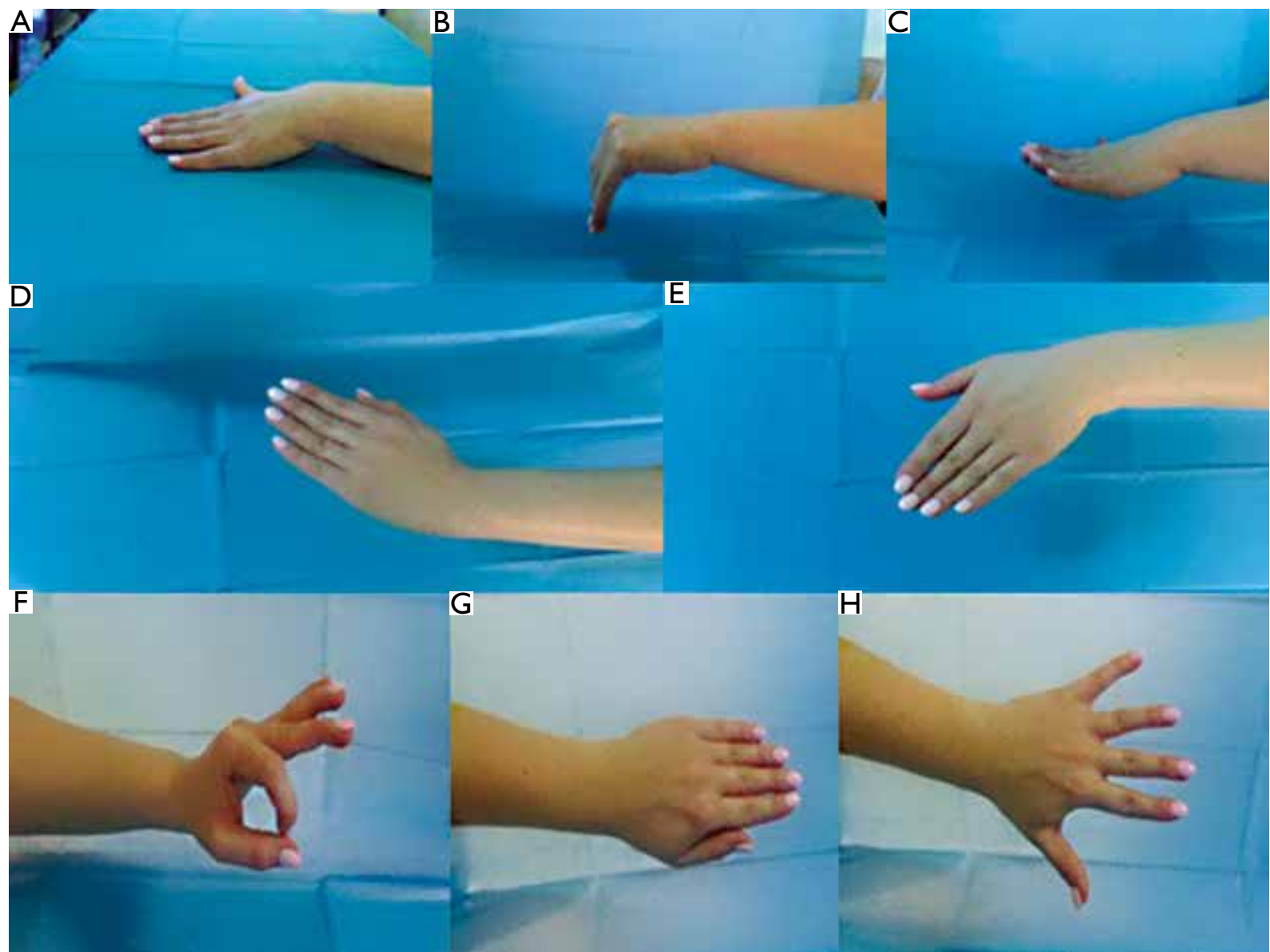

Figure I. Home exercises recommended for patients with SSc according to guidelines [ I 5]. A - Basic position, B, C - flexion and extension, D, E - radial and ulnar deviation of the wrist, F - tip-to tip pinch with opposition to the thumb, G, H - adduction and abduction of the fingers. Each session should last 20 min per hand

Rycina I. Program ćwiczeń domowych zalecany pacjentom z SSc na podstawie wytycznych [15]. A - Pozycja poczqtkowa, B, C - zginanie i prostowanie, D, E - odchylenie tokciowe i promieniowe nadgarstka, F-opuszką każdego palca należy dotknq̨́ kciuk, G, H - przywodzenie i odwodzenie palców. Czas trwania ćwiczeń - 20 min na każdq̨ rękę

approximately 20\% [8, 10, 21]. The beneficial effect of paraffin baths administered in combination with exercises was demonstrated both in patients with a recent disease onset and with the disease persisting for over 20 years [22-24]. Particularly noteworthy is the study by Sandqvist et al. in patients with systemic sclerosis $(n=17)$. One hand was subjected to therapy comprising a paraffin bath followed by exercises including finger flexion and extension, finger and thumb abduction, to be performed once daily for a month. The only therapy provided to the other hand, which represented the control, was the exercise programme. One month later, an improvement was observed with regard to finger flexion and extension, thumb abduction, wrist flexion, decrease in perceived stiffness and increase in skin elasticity on the hand treated with paraffin baths, as opposed to the control, where only finger and thumb flexion was found to have improved [21].
10, 21]. Dotychczas opublikowano kilka badań, w których stwierdzono korzyści z połączenia kąpieli parafinowych z ćwiczeniami zarówno u chorych z krótkim, jak i ponad 20-letnim czasem trwania choroby [22-24]. Na uwage zasługuje badanie przeprowadzone przez Sandqvist i wsp., w którym u pacjentów z SSC ( $n=$ 17) jedną rękę poddano terapii - kąpiel parafinowa z następującymi później ćwiczeniami obejmującymi zginanie i prostowanie palców oraz odwodzenie palców i kciuka (raz dziennie przez miesiąc), a drugą ręką stanowiącą kontrolę pacjent wykonywał jedynie ćwiczenia. Po miesiącu stwierdzono poprawę w zakresie zginania i prostowania palców, odwodzenia kciuka, zgięcia w nadgarstku, zmniejszenie odczuwanej sztywności oraz zwiększenie elastyczności skóry ręki poddanej kąpielom parafinowym w porównaniu $\mathrm{z}$ kontrolą, w której obserwowano jedynie poprawę w zakresie zginania palców i kciuka [21]. 
FACIAL REHABILITATION - HOME EXERCISES

For many years, microstomy rehabilitation was based primarily on self-administered exercises to stretch the oral aperture and improve mouth opening. Depending on the regime, exercises involved placing thumbs in opposite corners of the mouth and pulling outwards, placing wooden spatulas between the premolars of one dental arch and the molars on the opposite side or facial movement exercises based on a series of grimaces $[25,26]$. Study results published to date are difficult to compare because of the differences in the duration of exercises and the number of repetitions. Sometimes patients are advised to self-administer facial massage three times a day for 10-15 min. Each session should be preceded by the heating of tissues with a hot-water bottle [27].

On the other hand, facial rehabilitation based solely on home exercises does not always bring the desired and satisfactory effect because of patients' poor exercise adherence rate [26, 28]. As a result, an increased emphasis is being placed on the need to combine several physiotherapy methods.

\section{COMBINED REHABILITATION PROGRAMME FOR FACE INVOLVEMENT}

\section{Connective tissue massage}

The therapy should begin with connective tissue massage (CTM). The technique is based on the same principles as the connective tissue massage of the hands outlined above. Connective tissue massage should involve not only the face but also the neck and the periclavicular region. A single session should last approximately $10 \mathrm{~min}$, and sessions should take place twice a week $[18,26]$.

\section{Kabat's method}

The Kabat's method is a neurorehabilitation technique aimed at proprioceptive neuromuscular facilitation. The muscles are stimulated through stretching and resistance training. Rhe stimulated muscles include: orbicularis oris, zygomaticus, levator labii, nasalis, buccinator, occipitofrontalis and mimic muscles. The recommended duration of the procedure is about 15 min twice a week $[18,26]$.

\section{Kinesitherapy}

Kinesitherapy is the final element of the combined rehabilitation programme. It comprises passive and active exercises of the temporomandibular joint to increase the range of active motion and joint function, which improves the mouth opening ability. The recommended frequency is twice a week and the duration of one procedure is approximately $15 \mathrm{~min}[18,26]$.

\section{REHABILITACJA TWARZY - ĆWICZENIA DOMOWE}

Rehabilitacja mikrostomii przez wiele lat opierała się głównie na samodzielnym wykonywaniu ćwiczeń rozciągających i poprawiających otwieranie ust. W zależności od schematu pacjenci umieszczali kciuki w jamie ustnej w celu rozciągnięcia ust, umieszczali drewniane szpatułki pomiędzy zębami przedtrzonowymi jednego łuku zębowego a trzonowcami po stronie przeciwnej lub wykonywali serię ćwiczeń mimicznych naśladujących grymasy twarzy $[25,26]$. Wyniki dotychczas opublikowanych badań są trudne do porównania ze względu na różnice w czasie trwania poszczególnych ćwiczeń oraz liczbę powtórzeń. Czasami zaleca się samodzielne przeprowadzanie przez chorych masażu twarzy 3 razy dziennie po 1015 min, przy czym przed każdą sesją należy rozgrzać tkanki za pomocą termoforu [27].

Oparcie rehabilitacji twarzy wyłącznie na ćwiczeniach domowych nie zawsze jednak przynosi oczekiwany i zadowalający efekt ze względu na słabą współpracę z pacjentem podczas wykonywania ćwiczeń $[26,28]$. Dlatego coraz częściej zwraca się uwage na potrzebę skojarzenia kilku metod fizjoterapii.

\section{PROGRAM SKOJARZONEJ REHABILITACJI ZMIAN W OBRĘBIE TWARZY}

\section{Masaż tkanki łącznej}

Terapię powinno się rozpocząć od masażu tkanki łącznej. Masaż ten opiera się na tych samych zasadach co omawiany wcześniej masaż tkanki łącznej w obrębie rąk. Rekomenduje się przeprowadzenie masażu nie tylko w obrębie twarzy, lecz także szyi i w okolicy okołoobojczykowej przez ok. $10 \mathrm{~min}$ 2 razy w tygodniu $[18,26]$.

\section{Metoda Kabata}

Metoda Kabata jest techniką neurorehabilitacji, której celem jest proprioceptywne, nerwowo-mięśniowe torowanie wzorców ruchowych. Mięśnie są stymulowane przez rozciąganie i pracę z oporem. Zabiegi przeprowadza się w obrębie mięśni: okrężnego ust, jarzmowych, dźwigacza wargi, nosowego, policzkowego, potyliczno-czołowego i mimicznych. Zalecany czas stosowania to ok. 15 min 2 razy w tygodniu $[18,26]$.

\section{Kinezyterapia}

Kinezyterapia stanowi ostatni element skojarzonego programu rehabilitacyjnego. Polega na wykonywaniu biernych i czynnych ćwiczeń w obrębie stawu skroniowo-żuchwowego, poprawiających zakres 
The efficacy of combined rehabilitation (connective tissue massage, Kabat's method and kinesitherapy) complemented by home exercises was evaluated in a randomized study conducted in 40 patients with SSc. Nine weeks later, a considerable improvement was observed in the study group $(n=20)$ with respect to a decreased thickness of the facial fold assessed using the modified Rodnan skin score, an increased range of mouth opening measured in centimetres and improved oral cavity function evaluated by patients using the MHISS scale (Mouth Handicap in Systemic Sclerosis). Moreover, the effect in the study group persisted even 9 weeks after the completion of therapy. In the control group $(n=20)$, where the patients performed only home exercises, only mouth opening improved during first 9 weeks [26]. The fact that the clinical improvement was sustained for a longer period in patients with SSc is attributed by the authors not only to the efficacy of the rehabilitation methods used, but also to the continuation of home exercises by the patients after the completion of the study [26].

\section{Global rehabilitation techniques}

In addition to rehabilitation targeting the hands or face, some authors highlight the need to introduce global rehabilitation programmes, as the involvement of the musculoskeletal system also affects other body parts, resulting in pain and postural abnormalities [18, 29].

Hydrokinesitherapy, i.e. exercises in water at a temperature of $30^{\circ} \mathrm{C}$, are recommended in ulcerfree patients. Specially designed exercises performed in a pool, based on the physical properties of water, have a beneficial effect on the general motor performance in patients with systemic sclerosis [18]. Physical performance can also be improved with the help of diaphragmatic breathing exercises. By increasing exercise tolerance, they enhance the quality of life of patients [14].

\section{CONCLUSIONS}

The efficacy of rehabilitation in SSc has been evaluated to date in a few studies involving small groups of patients, with relatively short follow-up periods. The presented results pointed to a beneficial effect of rehabilitation on increasing hand mobility, enhancing the quality of life of patients, reducing microstomy and improving facial function. The rehabilitation programme seems to require individual adjustment depending on the stage of the disease. In view of the chronic and progressive nature of SSc, an important element of rehabilitation are physical exercises performed by patients at home as they offer a possibility to sustain effects achieved during rehabilitation. czynnego ruchu i funkcję stawu, co przekłada się na poprawę zdolności otwierania ust. Zalecany czas trwania to ok. 15 min 2 razy w tygodniu $[18,26]$.

Skuteczność skojarzonej rehabilitacji (masaż tkanki łącznej, metoda Kabata i kinezyterapia) uzupełnionej o ćwiczenia domowe oceniono w randomizowanym badaniu u 40 pacjentów z SSc. Po 9 tygodniach w grupie badanej $(n=20)$ obserwowano znaczące zmniejszenie grubości fałdu skórnego na twarzy ocenianej zmodyfikowaną skalą Rodnana, zwiększenie zakresu otwierania ust mierzonego w centymetrach oraz poprawę sprawności jamy ustnej ocenianej przez pacjentów w skali MHISS (Mouth Handicap in Systemic Sclerosis). Ponadto w grupie badanej efekt ten utrzymał się również 9 tygodni po zakończeniu terapii. W grupie kontrolnej $(n=20)$, w której chorzy wykonywali tylko ćwiczenia domowe, obserwowano poprawę jedynie w zakresie otwierania ust w czasie pierwszych 9 tygodni [26]. Dłuższe utrzymanie się poprawy klinicznej u chorych na SSc autorzy tłumaczą nie tylko skutecznością zastosowanych metod rehabilitacji, lecz także kontynuowaniem przez pacjentów ćwiczeń domowych po zakończeniu badania [26].

\section{Techniki usprawniania ogólnoustrojowego}

Cześć autorów zwraca uwagę na potrzebę wprowadzenia usprawniania ogólnoustrojowego oprócz rehabilitacji ukierunkowanej na ręce lub twarz, gdyż zajęcie układu mięśniowo-szkieletowego dotyczy także innych części ciała, co powoduje dolegliwości bólowe i zaburzenia postawy [18, 29].

Chorym bez owrzodzeń zaleca się hydrokinezyterapię, czyli ćwiczenia w wodzie o temperaturze $30^{\circ} \mathrm{C}$. Wykazano, że specjalne ćwiczenia wykonywane w basenie wykorzystujące właściwości fizyczne wody korzystnie wpływają na ogólną sprawność ruchową pacjentów z SSc [18]. Istotnym elementem poprawiającym sprawność są również ćwiczenia oddechowe angażujące przeponę. Pozwalają one na zwiększenie tolerancji wysiłku, przez co poprawiają jakość życia chorych [14].

\section{PODSUMOWANIE}

Skuteczność rehabilitacji w SSc oceniano dotąd w pojedynczych badaniach obejmujących niewielkie grupy chorych, a czas obserwacji był stosunkowo krótki. Przedstawione wyniki wykazały korzystny wpływ zastosowanej rehabilitacji na zwiększenie ruchomości ręki, poprawę jakości życia pacjentów, a także na zmniejszenie mikrostomii oraz zwiększenie sprawności twarzy. Wydaje się, że program rehabilitacyjny powinien być indywidualnie dobrany do fazy choroby. Ze względu na przewlekły i postępują- 
Further research is needed to develop protocols for rehabilitation and assessment of long-term effects of such therapy.

\section{CONFLICT OF INTEREST}

The authors declare no conflict of interest. cy charakter SSc istotnym elementem rehabilitacji są ćwiczenia wykonywane przez pacjenta samodzielnie w domu, które pozwalają na podtrzymanie uzyskanych efektów. Wskazane jest prowadzenie dalszych badań w celu opracowania protokołów rehabilitacji i oceny długoterminowych skutków takiej terapii.

\section{KONFLIKT INTERESÓW}

Autorzy deklarują brak konfliktu interesów.

\section{References}

\section{Piśmiennictwo}

1. Kowal-Bielecka O., Kuryliszyn-Moskal A.: Twardzina układowa. Reumatologia 2012, 50, 124-129.

2. Barsotti S., Stagnaro C., d'Ascanio A., Della Rossa A.: One year in review 2016: systemic sclerosis. Clin Exp Rheumatol 2016, 34 (Suppl 100), 3-13.

3. Varga J., Abraham D.: Systemic sclerosis: a prototypic multisystem fibrotic disorder. J Clin Invest 2007, 117, 557-567.

4. Kanecki K., Goryński P., Tarka P., Wierzba W., Tyszko P.: Incidence and prevalence of systemic sclerosis (SSc) in Poland differences between rural and urban regions. Ann Agric Environ Med 2017, 24, $240-244$.

5. Lis-Święty A., Brzezińska-Wcisło L.: Twardzina układowa - czynniki prognostyczne, aktywność i ciężkość choroby. Przegl Dermatol 2010, 97, 398-405.

6. Kowal-Bielecka O., Kuryliszyn-Moskal A.: Twardzina układowa. Reumatologia 2016, Suppl 1, 51-55.

7. Vitiello M., Abuchar A., Santana N., Dehesa L., Kerdel F.A.: An update on the treatment of the cutaneous manifestations of systemic sclerosis: the dermatologist's point of view. J Clin Aesthet Dermatol 2012, 5, 33-43.

8. Pietrzak A.: Rehabilitacja w wybranych chorobach skóry. [In:] Problemy rehabilitacyjne i zagadnienia pomocy społecznej osób niepełnosprawnych w Polsce. Karwat D. (ed.), Liber, Lublin 2002, 198-205.

9. Sandqvist G., Eklund M.: Hand Mobility in Scleroderma (HAMIS) test: the reliability of a novel hand function test. Arthritis Care Res 2000, 13, 369-374.

10. Casale R., Buonocore M., Matucci-Cerinic M.: Systemic sclerosis (scleroderma): an integrated challenge in rehabilitation. Arch Phys Med Rehabil 1997, 78, 767-773.

11. Thum-Tyzo K., Balawejder A., Tyzo B., Petkowicz B., Krasowska D., Wysokińska-Miszczuk J.: Występowanie zmian w jamie ustnej w przebiegu twardziny układowej. Dent Med Probl 2010, 47, 53-60.

12. Sharif R., Mayes M.D., Nicassio P.M., Gonzalez E.B., Draeger H., McNearney T.A., et al.: Determinants of work disability in patients with systemic sclerosis: a longitudinal study of the GENISOS cohort. Semin Arthritis Rheum 2011, 41, 38-47.

13. Bongi S.M., Del Rosso A., Passalacqua M., Miccio S., Cerinic M.M.: Manual lymph drainage improving upper extremity edema and hand function in patients with systemic sclerosis in edematous phase. Arthritis Care Res (Hoboken) 2011, 63, 11341141.

14. Antonioli C.M., Bua G., Frigè A., Prandini K., Radici S., Scarsi M., et al.: An individualized rehabilitation program in patients with systemic sclerosis may improve quality of life and hand mobility. Clin Rheumatol 2009, 28, $159-165$.

15. Bongi S.M., Del Rosso A., Galluccio F., Sigismondi F., Miniati I., Conforti M.L., et al.: Efficacy of connective tissue massage and Mc Mennell joint manipulation in the rehabilitative treatment of the hands in systemic sclerosis. Clin Rheumatol 2009, 28, 1167-1173

16. Kasseroller R.G.: The Vodder School: the Vodder method. Cancer 1998, 83 (Suppl 12), $2840-2842$.

17. Foldi E.: The treatment of lymphedema. Cancer 1998, 83 (Suppl 12), 2833-2834.

18. Bongi S.M., Del Rosso A., Galluccio F., Tai G., Sigismondi F., Passalacqua M., et al.: Efficacy of a tailored rehabilitation program for systemic sclerosis. Clin Exp Rheumatol 2009, 27 (Suppl 54), 44-50.

19. Cowen V.S.: Pathophysiology for Massage Therapists A Functional Approach. FA Davis Company, Philadelphia, 2016.

20. Mugii N., Hasegawa M., Matsushita T., Kondo M., Orito H., Yanaba K., et al.: The efficacy of self-administered stretching for finger joint motion in Japanese patients with systemic sclerosis. J Rheumatol 2006, 33, 1586-1592.

21. Sandqvist G., Akesson A., Eklund M.: Evaluation of paraffin bath treatment in patients with systemic sclerosis. Disabil Rehabil 2004, 26, 981-987.

22. Askew L.J., Beckett V.L., An K.N., Chao E.Y.: Objective evaluation of hand function in scleroderma patients to assess effectiveness of physical therapy. Br J Rheumatol 1983, 22, 224-232.

23. Pils K., Graninger W., Sadil F.: Parafin hand bath for scleroderma. Phys Med Rehabil 1991, 1, 19-21.

24. Mancuso T., Poole J.L.: The effect of paraffin and exercise on hand function in persons with scleroderma: a series of single case studies. J Hand Ther 2009, 22, 71-77.

25. Pizzo G., Scardina G.A., Messina P.: Effects of a nonsurgical exercise program on the decreased mouth opening in patients with systemic scleroderma. Clin Oral Investig 2003, 7, 175-178.

26. Bongi S.M., Landi G., Galluccio F., Del Rosso A., Miniati I., Conforti M.L., et al.: The rehabilitation of facial involvement in systemic sclerosis: efficacy of the combination of connective tissue massage, Kabat's technique and kinesitherapy: a randomized controlled trial. Rheumatol Int 2011, 31, 895-901. 
27. Kurhańska-Flisykowska A., Wyganowska-Świątkowska M., Buttner P.: Rehabilitacja mięśniowa w sklerodermii - opis przypadku. Dental Forum 2010, 38, 101-103.

28. Yuen H.K., Marlow N.M., Reed S.G., Summerlin L.M., Leite R.S., Mahoney S., et al.: Effect of orofacial exercises on oral aperture in adults with systemic sclerosis. Disabil Rehabil 2012, 34, 84-89.

29. Poole J.L.: Musculoskeletal rehabilitation in the person with scleroderma. Curr Opin Rheumatol 2010, 22, 205-212.

Received: 9.06 .2017

Accepted: 17.07 .2017

Otrzymano: 9.06.2017 r.

Zaakceptowano: 17.07.2017 r.

How to cite this article

Gerkowicz A., Bielecka A., Buś J., Polkowska-Pruszyńska B., Krasowska D.: Selected methods of rehabilitation in systemic sclerosis. Dermatol Rev/Przegl Dermatol 2017, 104, 385-395. DOI: https://doi.org/10.5114/dr.2017.69946. 